\title{
Authorial Strategies in Jean Bodin
}

\section{Citation}

Blair, Ann. 2013. Authorial strategies in Jean Bodin. In The reception of Bodin, ed. Howell A. Lloyd, 137-156. Leiden: Brill.

\section{Permanent link}

http://nrs.harvard.edu/urn-3:HUL.InstRepos:29669209

\section{Terms of Use}

This article was downloaded from Harvard University's DASH repository, and is made available under the terms and conditions applicable to Open Access Policy Articles, as set forth at http:// nrs.harvard.edu/urn-3:HUL.InstRepos:dash.current.terms-of-use\#OAP

\section{Share Your Story}

The Harvard community has made this article openly available.

Please share how this access benefits you. Submit a story.

Accessibility 


\title{
AUTHORIAL STRATEGIES IN JEAN BODIN ${ }^{1}$
}

\author{
ANN BLAIR \\ published in The Reception of Bodin, ed. Howell A. Lloyd (Leiden: Brill, 2013), 137- \\ 56
}

Authors are often themselves engaged in the reception of their works. ${ }^{2}$ They make decisions themselves and choose publishers and printers to make further decisions which shape how the work is first presented to readers--including choices about the front matter, lay-out and language of the work, and about format and length which affect price. Authors such as Jean Bodin (who started publishing at an early age and was active for over 40 years) were also able to contribute to the early reception of their works by responding to critics and adjusting their stance both in changes they made to the front matter and text of works which appeared in multiple editions in their lifetimes and in the new works that they published. In this chapter I will first identify some general patterns of Bodin's decisions as a prolific author in two languages and multiple fields and genres. I will then focus on how Bodin responded to critics of his République by using the voices of others to respond forcefully in the vernacular and by maintaining under his own name the persona of a dignified Latin author content to accept the judgements of others.

Thanks to the excellent research presented in the Bibliographie critique des éditions anciennes de Jean Bodin it is possible to track reliably the overall output of Bodin, in his lifetime and beyond. ${ }^{3}$ To summarise briefly the findings of this extensive survey conducted by the Séminaire de Bibliographie Historique of the University at Mons, Jean Bodin published nine major works for which he wrote dedications (the most 
explicit sign of an author taking responsibility for a work), many of which were reprinted during and after his lifetime:

-Bodin's translation of and commentary on Oppian's Cynegetica (1555, with 2

posthumous issues)

-the Methodus (Paris: Le Jeune, 1566; followed by 11 editions, 5 of them

posthumous)

-the Réponse à Malestroit (Paris: Le Jeune, 1568; Paris: Dupuys, 1578; then a further 7 editions, 3 of them posthumous)

-the République (Paris: Dupuys, 1576; then 13 editions, 3 of them posthumous)

-the Latin Republica, Bodin's own translation, including substantial revisions to the French edition, hence counted as a separate work (Paris: Dupuys, 1586; then 7

editions, 4 of them posthumous), followed by one edition each in Italian (1588), Spanish (1590), German (1591/92) and an English translation combining French and Latin versions (1606, posthumous)

-the Iuris universi distributio (Paris: Dupuys, 1578; then 2 editions, including 1 posthumous)

-the Démonomanie (Paris: Dupuys, 1580; then 12 editions, 4 of them posthumous); followed by translations into Latin (1581, plus 2 editions, one of them posthumous), in German (1581, plus 3 editions, one of them posthumous), and in Italian (1587, plus 2 editions, neither posthumous)

-the Theatrum (Lyon: Roussin, 1596, then 2 posthumous editions) and a posthumous French translation (1597)

-the Paradoxon (Paris: Duval, 1596), was followed by a French translation by Bodin published posthumously in 1598, and another French translation in 1604. 
This list of works for which Bodin composed a dedication omits a few shorter works which named Bodin on the title page, most of them born of specific circumstances, such as the Oratio of Toulouse (1559), Bodin's French translation of the Harangue to the Polish ambassadors (1573), and the Lettre de Monsieur Bodin (1590). The recent and painstaking survey of French vernacular books before 1601 led by Andrew Pettegree turns up two additional short works published in 1590, also without dedication and perhaps of dubious authenticity. ${ }^{4}$ Leaving aside these works which do not include a dedication and in the publication of which Bodin was not as closely engaged (whether for reasons of youth in 1559 or because others printed his Lettre probably without his consent), we can identify some broad trends in Bodin's authorial decisions for his major works. ${ }^{5}$

I.

\section{A few patterns of publication in Bodin's explicitly authored books}

Like all authors, Bodin had most control over the first editions of his works. Except in the case of the Theatrum, in first publishing his various works Bodin chose Paris publishers, first Martin le Jeune, then, starting in 1576, Jacques Dupuys with whom he developed a consistent relationship through to the end of his life. Dupuys was responsible for most of the editions of Bodin's works until he ceased activity in 1589; he produced the most important of them, the République and the Démonomanie, through five and four editions respectively, over seven years in each case. The first editions generally appeared in the largest formats: folio only for the République and the first editions of each of its translations (into Latin, Italian, Spanish, German, English); quarto for Oppian, Methodus, Réponse à Malestroit, Démonomanie; octavo for Iuris distributio, Theatrum and Paradoxon. In later editions Bodin's works all 
ended up in smaller formats - octavo in every case, in addition to smaller formats for the Methodus and for one edition of the Démonomanie. ${ }^{6}$ Apparent here seems to be an early version of the phenomenon that William St Clair has studied for the late eighteenth century which he calls tranching down (and which is still visible today in the use of hardback and paperback editions): publishers started by producing the most expensive editions possible, to tap the market of buyers who were willing to pay a top price, then reached new readers by printing subsequent editions in smaller and less expensive formats. ${ }^{7}$ Thus the first two Dupuys editions of the République were in folio, while the pirated 1577 Geneva edition was octavo, a format which Dupuys copied, starting with the third authorized edition in 1580 . The author may not have had much say in these decisions about format, even during his lifetime.

More reeditions of Bodin's works were published during his lifetime than afterwards (except for the Latin Republica) - an indication that Bodin's own activities helped foster interest in them. Nonetheless, Bodin's name was considered a selling point, to judge from the works that invoked it after his death, such as the Consilium Ioannis Bodini (1602) and the vernacular popularization of his Theatrum in the Problemata Bodini (1602). ${ }^{8}$ Likewise, Bodin's dedications were reproduced in almost all editions of his works, including the posthumous and even the pirated ones, presumably to highlight the value of the authenticity of his authorship. ${ }^{9}$

A translation significantly removed the work from its original author; the translations of Bodin's works routinely dropped the dedication by Bodin in favor of a dedication by the translator. Presumably, the heavy work involved in translation earned the translator the right to put himself and his relationships to his patrons forward. ${ }^{10}$ No translator took greater advantage of the opportunities for selfpromotion than François de Fougerolles, the translator of the Theatrum. While most 
translators' dedications were only a few pages long, Fougerolles devoted some 25 pages to his front matter - including a dedication, a preface and multiple odes of praise to himself and his work in Latin and Greek. He also took the printer to court to defend his right to control the front matter. ${ }^{11}$

But Bodin also published works without authoring them explicitly.

2.

\section{Beyond the explicitly authored works}

The Colloquium heptaplomeres poses notorious and especially complex problems. In refutation of recent challenges to the work's attribution to Bodin, Noel Malcolm has presented a detailed discussion of the evidence, and, beyond supporting his conclusions, I have nothing new to add to this debate. ${ }^{12}$ Malcolm concludes on the one hand that there will probably never be complete certainty concerning the authorship of the manuscript, but on the other that there is good circumstantial evidence for Bodin's authorship. He makes three main points especially. One of the earliest manuscripts includes both the Colloquium and the Epittre concernant l'institution de ses enfants for the latter of which Bodin's authorship has not been contested. Secondly, Malcolm finds that none of the evidence adduced by Karl Faltenbacher from allegedly anachronistic references is strong. Most powerfully in my view, Malcolm challenges the plausibility of contemporaries' attributing this text to Bodin (starting in the 1620s) without thinking the attribution was authentic. Indeed, he explains that when clandestine texts were given intentionally false attributions to famous authors in the early modern period, "the person so chosen was either a figure of solid respectability ... or a figure of notorious heterodoxy." Bodin was neither of the above: he "was too respectable to serve as an iconic anti-Christian, but not quite 
respectable enough to act as a façade for orthodoxy." ${ }^{13}$ In the absence of the association of Bodin with irreligion that began only in the late 17th century, Malcolm concludes, the near-contemporaries who attributed the Colloquium to Bodin did so because they felt they had good reason. Many of these reasons, such as the provenance of the manuscript or information transmitted orally, are no longer accessible to us, but make it plausible to privilege this contemporary attribution over other suggestions made in recent years.

If we set the Colloquium aside, Bodin published only one work anonymously: the Recueil de tout ce qui s'est negotié ... en l'assemblee generalle des trois Estats, 1577. This 129-page octavo booklet offered no authorship on the title page nor in the front matter, but plunged into a day-by-day account of the discussions at the 1576 Estates General of Blois, including third-person references to Bodin as the deputy for Vermandois. Its authorship has not been contested: the second edition (coinciding with the next meeting of the Estates General in 1614) labelled it as "pris des mémoires de M. I. Bodin l'un des deputez."

Bodin also published pseudonymously at least twice. The Sapientiae moralis epitome (Paris: Dupuys, 1588) listed Helias Bodin, Bodin's adolescent son, as the one who had gathered this collection of Latin moral distichs with facing French translation, but it is generally considered to be the work of Jean. ${ }^{14}$ Most interestingly for our purposes, since the late seventeenth century (but perhaps not before then) Bodin has been considered the author of the Apologie de René Herpin pour la République de Jean Bodin, first published in freestanding form in 1581 by Jacques Dupuys, then appended to French editions of the République starting in 1583. Interestingly, Richard Knolles, translator of the République into English in 1606, took at face value the authorship of the Apologie by this René Herpin (who is otherwise unknown to the 
historical record). Indeed, Knolles cited approvingly in his own preface to the English translation from the Latin letter printed in the Apologie that Herpin supposedly had received from Bodin explaining why the author would not reply to his critics himself: So that in defence of him [Bodin], as also of this my Translation, I will use no other Apologie than that which he yet living in few words most mildly used, in an Epistle to a friend of his [that is, Herpin], persuading him not so to put up the matter: Satis opinor, mea me scripta, et vitae ante-actae rationes, ab improborum contumelia vindicabunt: I suppose (said he) my writings, with the course of my fore-passed life, shall sufficiently defend me from the reproach and slander of envious and malitious men. ${ }^{15}$

Thus twenty-five years after the first publication of the Apologie, Knolles did not question the claim that the Apologie was written by a friend and compatriot of Bodin's to defend Bodin in the face of attacks against the République, given the author's unwillingness to do so himself.

The earliest mention of Herpin as a pseudonym for Bodin that I have found so far is in Adrien Baillet, Jugemens des sçavans (1685). ${ }^{16}$ Baillet is the source given by Vincent Placcius in listing Bodin/Herpin in his dictionary of pseudonymous and anonymous writings of $1708 .^{17}$ (Interestingly, neither the Colloquium heptaplomeres nor Bodin features in Placcius' discussion of anonymous manuscripts. ${ }^{18}$ ) Thereafter the Bodin/Herpin identification became standard in modern library catalogues and lists of pseudonymous works. But already in 1584, just three years after the first publication of the Apologie, the French bibliography of La Croix du Maine listed Herpin as an "assumed and feigned name," but without identifying Herpin with Bodin himself. The name Herpin figures in the text and the index of Knolles' Six Books concerning "Philip I of Herpin" purchasing the duchy of Berry for 60000 crowns in 
the 15 th century, but Knolles does not attempt to draw any connection to a person living in Bodin's day. ${ }^{19}$ The 1772 update of the work, with annotations by de la Monnoye, repeated the entry of 1584, while noting the claim of Gilles Ménage (161392) that the name Herpin referred to a real person in Angers. But the Herpin/Bodin equivalence was made explicit in another entry of the bibliography: the discussion of Michel de La Serre (in a passage not present in the edition of 1584) notes that Bodin replied to de La Serre's Remonstrance under the name of René Herpin. ${ }^{20}$

Although in the late sixteenth century some contemporaries considered Herpin to be an assumed name (very likely because he was otherwise unknown as an author), they did not identify Herpin with Bodin. Yet there has been no challenge to the notion that Herpin was in fact a pseudonym for Bodin once this claim was first made in the late seventeenth century. I will develop this assumption by analyzing Bodin's use of Herpin and his parallel reliance on an avis au lecteur by his printer Jacques Dupuys in the editions of the République of 1578-83. I argue that Bodin deployed a two-tiered strategy for replying to critics of the République: Bodin reserved for himself a stance as a Latin author reluctant to engage in polemic while an acolyte (his printer or the supposed friend Herpin) engaged in vehement invective against Bodin's critics in the vernacular.

3.

\section{Bodin's strategy for responding to critics}

The République_was a rapid success from its first publication in 1576, and Dupuys reprinted it within a year. But in 1577 an unauthorized and modified edition was printed in Geneva, with no place of publication nor printer mentioned. Corinne Müller explains how Claude Juge, a major Geneva printer, had requested permission 
from the council of that city to publish the work, but the council required that the work be revised before publication and assigned that task to the respected Geneva pastor, Simon Goulart. ${ }^{21}$ The preface to the Geneva edition (presumably by Goulart) explains that modifications were made to Bodin's text to correct errors of multiple kinds. These included errors of fact concerning the political system of Geneva and its relations with the canton of Bern, and errors of interpretation on the hot topic of the day - the legitimacy of rebelling against a ruler. Goulart took Bodin to task for citing only passages in Calvin and Luther that forbade rebellion, while Goulart adduced passages in which both rather seemed to authorize rebellion. In one of the final paragraphs of his Institution chrétienne book IV Calvin suggested that the magistrates though not the people might legitimately rebel against a tyrant; and Luther, as reported by Sleidan, supported rebellion against Charles V. ${ }^{22}$ Goulart concluded: "Bodin adduces only that which seems to him to support his intention, without considering carefully what one could argue against it."23 Goulart also criticized Bodin's reference to astrological conjunctions to explain the rise and fall of states.

The unauthorized publication of the Geneva edition was obviously traumatic to both author and publisher. It was the first time that Bodin was attacked in print. The Methodus of 1566 would elicit criticism from Germans unhappy with Bodin's debunking of the traditional interpretation of Daniel's prophecy on the four empires and the place of the Holy Roman Empire in that genealogy, but that criticism appeared only after the République rehearsed Bodin's arguments against the four monarchies a decade later. ${ }^{24}$ The stakes of the debates surrounding the République were also especially high, since they occurred in the midst of civil wars and of the radicalization of political ideas between monarchomach writings on the one hand and 
pro-Catholic League preaching on the other. These political tensions would affect editions of the République in French and Latin through the 1590s. ${ }^{25}$

Bodin and Dupuys took action immediately in the third authorized edition of the République in 1578 (which Dupuys acknowledged was actually the fourth edition, if one counted the unauthorized Geneva edition). In addition to the original French preface by Bodin to Guy du Faur de Pibrac, conseiller du roi en son privé conseil, Bodin added an epistola to the same. This Latin letter to his patron was the only text in Latin in a book which Bodin had quite deliberately chosen to write in French, as he explained, because Latin learning was running dry during the period of wars and because he wanted to be understood by his ordinary countrymen ("Français naturels"). ${ }^{26}$ The anomaly of the intruding Latin letter was ostensibly explained in the piece of front matter immediately following the epistola. In an avis au lecteur the printer Jacques Dupuys railed against the unauthorized Geneva edition for undercutting his own legitimate one to line the pockets of the printer Claude Juge, whom Dupuys called an erstwhile draper who had dabbled in alchemy. Dupuys lashed out with sarcasm:

This reverend master [the Geneva printer Juge] has been so courteous toward both author and printer that, after seeking to steal honor from the first and profit from the second, he has tried to convince you that he has corrected the errors of both. As for the author [Bodin], I believe that he has pen in hand to respond when it pleases him to. That fact notwithstanding I have still wanted to include a Latin epistle that he sent to Monsieur de Pibrac, which I recovered by an intermediary [par moyen], to erase the opinion that those [Geneva] boasters have tried to impress on your brain. ${ }^{27}$ 
Thus Dupuys suggested that he had procured and published on his own initiative this private letter from Bodin to du Faur de Pibrac, which was ostensibly written to congratulate the latter on his recent promotion to the office of président à mortier of the Paris Parlement.

It is clear, however, that Dupuys was operating in concert with Bodin. For one thing, Dupuys remained Bodin's choice of printer for the rest of the printer's career, so he certainly had done nothing to anger Bodin, as would have been the case if he had published a private letter of Bodin's without the author's consent. ${ }^{28}$ Furthermore, the combination of Bodin's Latin letter and Dupuys' French avis formed a double strategy in which French invective by the printer settled the score for all to see, while Bodin himself offered a learned, unemotional response to a few broad criticisms in Latin to emphasize his membership of the international community of scholars. In his epistola Bodin first responded to the criticism of the learned Jacques Cujas (1520-90), a rival lawyer with whom Bodin had been hostile since his student days and who had attacked him for criticizing a grammatical approach to the law. Bodin upheld his original critique, but graciously conceded that he too used to believe in the grammatical approach, before he experienced the value of legal practice. ${ }^{29}$ Bodin used the République to reinforce his position against Cujas (see the additions made to the 1583 edition discussed in note 52), but the tension between a grammatical approach to the law and one based on more recent experience and examples, as favoured by Bodin, was a long-running intellectual debate rather than the hot political issue of the day. Next in his Latin letter, Bodin addressed the criticism (which he did not attribute to anyone in particular) that he had assigned too much power to the sovereign at the expense of the people. ${ }^{30}$ Bodin denied the charge by referring to his recent interventions at the Estates General of 1576 in which he objected to the alienation of 
crown property, thus acting in the interest of the people against the will of the sovereign himself. After shifting curiously to the third person to describe his interventions at the Estates General (mimicking his account of the meeting in the anonymously published Recueil), Bodin also added bitterly that his political stand had cost him a position of maître des requêtes that he claimed the king had designated for $\operatorname{him}^{31}$

In this Latin epistle, accessible to only some of the readers of the French République, Bodin defended himself without attacking his most recent enemies and rehashed the recent personal trauma of his loss of influence at court. The sharp attacks on the Geneva printer and editor were left to Dupuys' French avis. Epistola and avis appeared together in the two further editions of the République printed by Dupuys in 1580 and 1583 , but the avis, with its explicit hostility to Geneva, was dropped from the Lyon editions $(1579 / 80,1587,1593,1594)$, probably in order to help these editions sell in nearby Geneva, and a fortiori from the last French editions, which were printed in Geneva in 1599, 1608 and $1629 .{ }^{32}$

The République also elicited criticism from other quarters than Huguenots keen on justifying rebellion. In 1579 one Michel de La Serre published a polemical Remonstrance au Roy in which he accused Bodin on the contrary of offering tacit support for the monarchomachs and of inviting foreign intervention into French affairs. ${ }^{33}$ This charge that Bodin was a monarchomach sympathizer was far more serious than the Genevan concern that Bodin was not favourable enough to the possibility of rebellion. We catch a glimpse of the appeal for redress that Bodin probably made directly to the king through his recounting of the punishment that the king ordered for de La Serre. And refuting the critique of de La Serre was Bodin's first goal in publishing the Apologie, initially, in 1581, as a separate work of 88 pages, 
which then became a standard appendix to editions of the République starting in 1583. The Apologie de René Herpin pour la Républicque de I. Bodin first addressed criticisms by de La Serre, then those of André Frankberger (on the prophecies of Daniel) and Pierre d'Ostal (on arithmetic, geometric and harmonic ratios) before devoting the bulk of the page count to Auger Ferrier, a former friend whose criticisms of Bodin's astrological computations angered Bodin especially. ${ }^{34}$

The Apologie engaged in a tactic similar to the combination of Latin letter and French invective by someone other than Bodin in the front matter of editions of the République. The Apologie was couched as the work of a friend and compatriot of Bodin, René Herpin, who was indignant at the attacks on Bodin and at Bodin's lack of response. To explain his motivation Herpin reproduced a Latin letter which Bodin had supposedly written to him in response to his (and other friends') urging Bodin to reply to his contumacious critics. This is the letter that Knolles cited at face value in 1606 . Whereas Herpin raged about the affront to Bodin's honour - that good which is more precious than life itself - in the Latin letter Bodin detached himself from replying to his critics, explaining:

I am surprised at you, Herpin, who are adorned by doctrine and nature so well, that you urge your friends to this contentious type of writing which is hardly praiseworthy and is often abused - I have seen no one use it in moderation. You should rather be exhorting me to the patience and modesty that accompanies true honor. Why not bear patiently the just reprehension of friends or foes?

Bodin went on to opine (as Knolles quoted in Latin and translated admiringly): "I suppose that my writing with the course of my previous actions shall sufficiently defend me from the reproach and slander of envious and malicious men." ${ }^{35}$ In other 
words, Bodin explained that he did not fear unfair attacks, since he was confident that his actions and past writings would vindicate him.

But Herpin criticized Bodin's stance of aloofness, developing over the next few pages a history and theory of honour that justified rebutting Bodin's critics with vehemence. First, Herpin pointed out that authors can never defend their own selves well, which is why French law wisely decreed that no person should plead his own case. Indeed Herpin explained:

it is hard for someone who is defending his honour (which is worth more than the benefits of life) not to be transported by violent passions or forced to do things which one cannot say without blushing with shame, and especially when honour is at stake, which we treat differently from the ancients. Herpin was conscious of the rules concerning honour having changed since ancient times; in particular, he implied, boasting about oneself was now considered shameful. ${ }^{36}$ Herpin also reflected on the development over time of strictures against personal attacks:

[In times past] poets and players [joueurs de farces] spoke ill of people by name, causing so many quarrels that speaking ill of others was forbidden in harsh terms, so that everyone took care not to write against the honour of individuals. But when it comes to defending Religion against atheists or the commonweal against its oppressors, piety toward God on the one hand and love of country on the other hand have always excused those who guard jealously the honour of God or the commonweal. For, as Theophrastus said, it is hard for a good man not to speak ill of those who are evil. ${ }^{37}$ 
Thus a vitriolic attack on heresy or sedition might be justified, but only in defence of true religion or government; despite this caveat Herpin nonetheless went on to condemn acerbic criticism. ${ }^{38}$

The earliest authors, Herpin observed, among both the Greeks and the Hebrews, were considered "as holy and inviolable." To illustrate this point Herpin told the story of Zoilus, which Bodin also mentioned elsewhere: having written against Homer, Zoilus was precipitated to his death from the Schirronidean rock. "Though many found some of his criticisms well founded, it was considered inexcusable to attack such a person [as Homer] who was like an honoured patron to all peoples and princes. ${ }^{139}$ Although few French authors referred to Zoilus, this figure featured in many early modern English writings as the archetype of the envious critic; perhaps Bodin picked up the reference while in England, though it was retold also in a few major Latin reference works of the time. ${ }^{40}$ Herpin attributed the beginnings of contumacious criticism to Aristotle (Bodin's favorite whipping boy), who was the first to violate "the laws and religion of honour" and was criticized "by all the academicians for having not only wrongly criticized their master [Plato] but also calumniated him." 41

This accumulation of examples of critics, characteristic of Bodin's mode of argumentation on many topics, culminated in the conclusion that the state should protect learned men from unfair criticism because of their value to the common good. Although one who treats a science may attack the impiety of the wicked with acerbic words, or the error of those who have failed, with the modesty appropriate to men of letters. Nonetheless it sets a bad and pernicious example to attack the honour of learned men, under pretext of some mistake, and to heap on them contumacious words in the manner of Pedants, as reward and 
repayment for their labor: in which the Commonweal has a notable interest: and this is even more true if one attacks honour through defamatory libels, as one man who has himself called de La Serre has done some six or seven months ago against the République of Bodin. ${ }^{42}$

Bodin had referred to de La Serre in the Latin letter inserted in the Apologie, noting simply that for attacking Bodin that critic was punished more severely than the former could have hoped. A few pages later Herpin writing in French spelled out in detail a story of authorial vindication by the Crown of which Bodin must have been very proud - so proud that he could not tell it in his own voice lest he appear immodest: Two calumniators who never stopped barking in public against the République went to the King to have the work forbidden; the King had the seigneur d'Oron, Royal Reader, who had read the République of Bodin, tell them that if they had something to say against Bodin, they should put it in writing, so that it could be judged. Instead of their doing so, someone named de La Serre had a little booklet printed which he dedicated to the King. Having read it and recognized the gross calumnies it contained, the King asked the civil lieutenant to imprison de La Serre and signed the decree in his hand, and forbade the printer, on pain of death, to display the book for sale. ${ }^{43}$

But de La Serre's pamphlet was most likely available for sale nonetheless - certainly copies survive - and Bodin admitted elsewhere that de La Serre got off without imprisonment, paying only a fine.

In the persona of the ideal learned author, modest, moderate and uninterested in polemic, Bodin wrote that de La Serre was punished more than he could have hoped (interestingly the modest author could still acknowledge hoping for his critic's punishment). ${ }^{44}$ But in the preface to the Démonomanie Bodin told the same story only 
to express resentment that de La Serre had got off lightly whereas he deserved the fate of Zoilus himself: death for his contumaciousness. ${ }^{45}$ In the preface of the

Démonomanie Bodin forestalled any criticism by noting that the only critics the work might encounter would be sorcerers seeking to defend themselves. ${ }^{46}$ And in his Refutation des opinions de Jean Wier appended to the Démonomanie Bodin did not shy away from vitriolic attack. In this case he presumably felt confident that his vitriol was of the acceptable kind because it was directed against the wicked in defence of true religion.

Bodin had one more opportunity to respond to attacks on the République in the Latin version that he himself prepared in 1586: but that preface followed the patterns of the moderate Latin Bodin without responding to the political criticisms from Geneva or de La Serre. Instead, Bodin addressed the criticisms he had expected to receive in earlier works concerning the length of his work: some might find it too bulky, while others might find his treatment of certain topics too brief. ${ }^{47}$ In doing so he returned to a theme present in the dedications of the French République and of the Methodus, in which Bodin addressed the potential criticism that his book was too long. It was not too long, he observed, when compared with the 6000 books of grammar by Diomedes, given the greater scope and significance of his topic. ${ }^{48}$

In cultivating in Latin the persona of the moderate learned author while entering the fray of vernacular political polemic through the voice of others, Bodin displayed careful skill in shaping the reception of his works and the construction of his personal reputation. ${ }^{49}$ A further manifestation of Bodin's sense of himself as an author which might reward study, though it is less clear how self-conscious it was, concerns his use of personal pronouns. In his dedications and here and there throughout his works Bodin regularly adduced personal experience (as studied by 
Greengrass in this volume) and motivation by speaking in the first person singular; but occasionally Bodin used the first person plural instead, notably to describe the actual process of writing or revising a work, as in the preface to the Latin Republica. ${ }^{50}$ Bodin also referred to himself in the third person as an actor on the political stage (in the Recueil and passages reporting on the Estates General in the République ${ }^{51}$ ) and, strikingly, in a few additions concerning his criticism of Cujas first made in the République of $1583 .{ }^{52}$ Do these third-person references to Bodin's disagreements with Cujas result from his displeasure at engaging directly (for example with first person pronouns) in a scholarly dispute? Or do they, along with the use of 'we' in describing the process of writing the Republica, offer a clue that Bodin might at some points have worked with the help of others? ${ }^{53}$ More interesting still would be to ascertain what impact Bodin's choices of pronouns had on near-contemporary readers (including whether they went completely unnoticed). Even in the absence of evidence about the impression made on readers by his choices, we can certainly observe Bodin at work in shaping the reception of his works and reputation through the use of multiple voices and personae throughout his numerous writings.

\footnotetext{
${ }^{1}$ I am grateful to the organizer and participants in the Hull workshops for many insightful comments at the time and afterwards. Special thanks to Sara Miglietti for the passages in the Methodus that support the themes I discuss here, and to MarieThérèse Isaac of the University Mons, Belgium, for sharing with me copies of prefaces of hard-to-find editions collected by the Séminaire de Bibliographie Historique during its study of Bodin's works in the 1980s.
}

${ }^{2}$ Cf Peter Burke's comment on 'paratexts' above [Burke chapter, p. 13]. 
${ }^{3}$ Ed. Roland Crahay, Marie-Thérèse Isaac, Marie-Thérèse Lenger, with René Plisnier (Brussels: Académie Royale de Belgique, 1992).

${ }^{4}$ Copie des lettres missives escrites à un sien amy contenant plusieurs poincts notables de l'estat present de la France (n.pl. n.pub.,1590) and Discours sur aucunes parties de l'estat du magistrat (n.pl. n. Pub. [1590]) are not listed in Crahay et al. eds., Bibliographie critique des éditions anciennes de Jean Bodin but appear in French Vernacular Books: books published in the French language before 1601, ed. Andrew Pettegree, Malcolm Walsby, Alexander Wilkinson (Leiden: Brill, 2007), 178-80 on Bodin, FB6180 and 6182.

${ }^{5}$ See Crahay et al., eds., Bibliographie critique, 16-17, 84-90. On Bodin's displeasure with the printing of his Lettre, see Paul Lawrence Rose ed., Jean Bodin. Selected writings on philosophy, religion and politics (Geneva: Droz, in association with James Cook University of North Queensland, 1980), xii.

${ }^{6}$ Jonathan Schüz's paper in this volume points out that, in a reversal of this general trend, the German edition of the Demonomania of 1591 was published in folio format, after the first two editions had been octavos. See also Crahay et al., eds., Bibliographie critique, 272-73. The Methodus was printed in in-16 format in 1591, $1598 / 99,1607,1627$; and in in-12 in 1650; octavo editions appeared in 1572, 1576, 1583, 1595 and 1610. The Démonomanie was printed in in-12 format in 1598 and 1604. 
${ }^{7}$ See William St. Clair, The Reading Nation in the Romantic Period (Cambridge: Cambridge University Press, 2004), e.g. 32, or "The Political Economy of Reading," John Coffin Memorial Lecture in the History of the Book. London: University of London, 2005. Accessible on-line at $<$ http://www2.sas.ac.uk/ies/Publications/johncoffin/stclair.pdf $>$

${ }^{8}$ See Crahay et al., eds., Bibliographie critique, 329-31 and 306-11, and on the Problemata Bodini, see Ann Blair, The Theater of Nature: Jean Bodin and Renaissance Science (Princeton NJ: Princeton University Press, 1997), 212-24.

${ }^{9}$ The only exceptions I have noticed, in which Bodin's dedication was omitted from a later of edition of a work for which he had written a dedication, are the editions of the Démonomanie of Antwerp, 1592 and of Rouen, 1604.

${ }^{10}$ One exception to the omission of Bodin's original dedications in translations occurs in the 1604 Paradoxe which includes Bodin's dedication after the translator's.

${ }^{11}$ See Blair, The Theater of Nature, 204-7.

12 Noel Malcolm, "Jean Bodin and the Authorship of the Colloquium heptaplomeres," Journal of the Warburg and Courtauld Institutes 69 (2006): 95-150. On the challenge to the attribution to Bodin see especially Karl Faltenbacher, Der kritische Dialog des Colloquium Heptaplomeres: Wissenschaft, Philosophie und Religion zu Beginn des 17. Jahrhunderts. Ergebnisse der Tagung vom 6. bis 7. November 2006 am FrankreichZentrum der Freien Universität Berlin, in Beiträge zur Romanistik, vol. 12 
(Darmstadt, Wissenschaftliche Buchgesellschaft, 2009). For further materials

presented from this perspective see the website maintained by Karl Faltenbacher at http://www.heptaplomeres.de/

${ }^{13}$ Malcolm, "Jean Bodin," 148-49.

${ }^{14}$ Rose, ed., Jean Bodin. Selected Writings, pp. v-vi.

${ }^{15}$ Richard Knolles tr., The Six bookes of a commonweale (1606), preface, in Kenneth D. McRae, ed. facsimile edition (New York: Arno Press, 1979), p. [vi].

${ }^{16}$ Adrien Baillet, Jugemens des sçavans (Amsterdam: aux dépens de la Compagnie, 1725; first published 1685), V, 329 ("liste des auteurs déguisés"): "Herpin, René: Jean Bodin." Baillet offers no discussion of the attribution.

17 Vincent Placcius, Theatrum anonymorum et pseudonymorum (Hamburg: Liebernickel, 1708), Pseudonyma, p. 348: "(1341) HERPIN, René: Jean Bodin. Baillet ibid p. 563." In the shorter edition of his Dictionarium in 1674 Placcius mentioned Bodin only to cite the accusation of plagiarism made by Conrad Rittershusius in a letter to Richter, that Bodin had derived his commentary on Oppian's poem on hunting from the lessons of Adrien Turnèbe. Ritterhusius cited Bodin while defending himself against a charge of having adorned with the "feathers of others" a recent panegyric of his own and offers no substantiating detail. "Equidem mirari satis nunquam potui, tam apud veteres Graecos et Latinos, quam superioris seculi Viros magni nominis aliena scripta tota transcripsisse, sine ulla immutatione aut 
mentione aucotrum, pro suis edidisse. Bodinus lectiones Turnebi in Oppianum pro suis vulgavit. Quid Scioppius Giphanio harpagarit, notum est doctis." Georg Richter, Epistolae selectiores (Nurnberg: Michael Endter, 1662), p. 205. Baillet dismissed the charge--at most Bodin took some of Turnèbe's corrections (in edition of 1725: vol. 2, p. 183, paragraph 413).

${ }^{18}$ Placcius, Theatrum, offers no indexing of the anonymous works; I have looked for the Colloquium in the section on French manuscripts without success. I am grateful to Martin Mulsow for lending his expertise to this search too.

19 "[T]he duchie of Berrie was bought by Philip the I of Herpin, for threescore thousand crowns." Knolles, p. 667. Knolles seems to have misinterpreted the Latin which describes Philip buying the city of Berry from Herpin: "Item Philippum I. Biturigum urbem amplissimam agrumve Biturigensem ab Herpino duce sexaginta millibus aureorum emisse." Republica (1586), 658. The French text drops the mention of Herpin: "le Duché de Berri ne fut acheté que soixante mil reaux d'or par Philippe premier." République (1583), 883.

${ }^{20}$ François de La Croix du Maine, Bibliothèques françoises de La Croix du Maine et de du Verdier (Paris: Saillant et Nyon, 1772), II, 369: "RENÉ HERPIN qui est un nom supposé \& contrefait. II a écrit une bien ample apologie ou réponse pour la république de Jean Bodin Angevin imprimée sur la fin de ladite république des dernières éditions. Note [added in 1772]: Ménage dans ses Remarques sur la vie de Pierre Ayrault p 143 dit que ce René Herpin étoit un homme de la ville d'Angers. Ainsi quoique ce soit un nom supposé ce n'est pas un nom imaginaire ou fait à plaisir 
(M de la Monnoye)." The same entry without the note appears in La Croix du Maine, Premier volume de la bibliothèque (1584), p. 436. In 1772 the entry for Michel de La Serre lists his Remonstrance with this further note: "Bodin y repondit sous le nom de René Herpin"; La Croix du Maine, Bibliothèque, II, 137. But this identification does not appear in 1584 (see there p. 331). On de La Serre see also below, p. 12.

${ }^{21}$ Corinne Müller, "L'Édition subreptice des Six Livres de la République de Jean Bodin (Genève, 1577). Sa genèse et son influence," Quaerendo (Amsterdam) 10:3 (1980): 211-36.

${ }^{22}$ Sleidan, Histoire de l'état de la religion (1558), 220 as cited in Müller, 'L'Édition': 229.

23 "C'est que Bodin allegue seulement ce qui luy semble convenir à son intention, sans considerer exactement ce qu'on pourroit bien dire au contraire." République (1577), sig. $* 4$ r.

${ }^{24}$ Bodin is my source for this point: "Ceste opinion de Bodin [que la prophetie de Daniel ne se peut accommoder à la Monarchie des Romains ... ny que l'Empire d'Alemaigne, soit la Monarchie des Romains] a depuis esté suyvie de plusieurs personnes, et mesmes de plusieurs Allemans ... et ne s'est trouvé personne qui ait escrit au contraire, iusques à ce que Bodin à [sic] publié sa republique, où il escrit, qu'il ne faut pas s'arrester au dire de Luther...." Apologie (1583), ff. 5v-6r. 
${ }^{25}$ For an entry into this broader context, see Mack Holt, The French Wars of Religion, 1562-1629 (Cambridge: Cambridge University Press, 1995) and J. H. Burns and Mark Goldie eds., The Cambridge History of Political Thought, 1450-1700 (Cambridge: Cambridge University Press, 1991), chs. 7-10.

26 "C'est pourquoy de ma part ne pouvant rien mieux, i'ay entrepris le discours de la Repub. et en langue populaire, tant pour ce que les sources de la langue Latine sont presque taries, et qui seicherot [sic for seicheront] du tout si la barbarie causee par les guerres civiles continue, que pour estre mieux entendu de tous François naturels." République (1583), sig. aij verso.

27 "Ce maistre reverend a esté si courtois ... envers l'auteur et libraire, que ayant pretendu voler l'honneur à l'un et le profit à l'autre, s'est efforcé à vous faire entendre, qu'il a corrigé les fautes de tous deux: quant à l'auteur, je croy qu'il a plume en main pour s'en resentir quand bon luy semblera. Ce nonobstant i'ay encore bien voulu mettre une epistre Latine qu'il a envoyé a monsieur de Pibrac, laquelle i'ay recouvree par moyen, pour effacer l'opinion que ses beaux advertisseurs se sont efforcez vous imprimer au cerveau." République (1583), sig. eij recto (first published, 1578).

${ }^{28}$ Dupuys printed all the first editions of the works that Bodin explicitly authored (and one published under the pseudonym of Bodin's son) from the République (1576) down to the end of his activity in 1589 (on his date of death see http://www.lycosthenes.org/dupuis.html): Sur le rehaussement et diminution des monnaies (1578, a revised and augmented version of the Réponse aux paradoxes de 
Malestroit of 1568), Iuris distributio (1578), Démonomanie (1580), Apologie de René Herpin (1581), Sapientiae moralis epitome (1588).

29 "Si tamen error veniam meretur, Cuiacium quodammodo venia dignum putem, cum ipse in eodem errore fuerim, de quo quidem confiteri non pudet. Fuit enim tempus illud, cum populi Romani iura publice apud Tolosates docerem, ac valde sapiens mihi ipsi viderer in adolescentium corona... Postea vero quam in foro iurisprudentiae sacris initiatus, ac diuturno rerum agendarum usu confirmatus sum, tandem aliquando intellexi non in scolastico pulvere, sed in acie forensi: non in syllabarum momentis, sed in aequitatis ac iusticiae ponderibus veram ac solidam iuris sapientiam positam esse: eos autem qui forenses literas nesciunt, in maxima Romani iuris ignoratione versari." Epistola, République (1583), sig. [a7]r-v (first published 1578). Cujas was older than Bodin but moved in the same circles, having studied at Toulouse and taught Guy du Faur de Pibrac, a powerful Toulouse nobleman whose patronage Bodin also sought notably in the dedication of his République. Cujas's 19th-century biographer calls Bodin a sworn enemy of Cujas's who mounted a cabal to prevent him from being named for a professorship at Toulouse. On Cujas as teacher of Guy du Faur de Pibrac, see Alban Cabos, Guy du Faur de Pibrac, un magistrat poète au XVIe siècle (Paris: Champion and Auch: Cocharaux, 1922), 24-25; on the enmity of Bodin, see Jacques Berriat-Saint-Prix, Jacob Cujas und seine Zeitgenossen (Leipzig: J. F. Hartknoch, 1822), 134-35.

30 "Miror tamen esse qui putent unius potestati tribuere me plus aliquantum, quam deceas [for deceat] fortem in Republica civem, cum alibi saepe, tum vero libro primo, capite octavo nostrae Reipublicae, eos ego qui de iure fisci ac regalibus amplificandis 
scripsere, sententias primus omnium, et quidem periculosissimus [sic for -is] temporibus refellere non dubitarim, quod Regibus infinitam supraque divinas et naturae leges tribuerent potestatem: quid autem magis populare quam quod scribere ausus sum, ne regibus quidem licere, sine summa civium consensione, imperare tributa?" Epistola, République (1583), sig. [a8]r-v

31 "Cum vero praedia publica sub hasta vendere et quidem alienatione sempiterna, ac tributa duplicare specie levandae plebis propositum esset, idque modis omnibus tentaretur, nos tanto studio intercessimus, ut cum nihil obtineri potuisset, Rex ipse Homaro Burdegalensium Praeside, Dureto Praeside Molineorum, Ripuario Aquitaniae sindico, ac plerisque aliis audientibus dixerit, Bodinum ab eius commodis non modo dissentire, verumetiam collegarum voluntates ac studia a se avertere consuesse.... Ex eo tamen quantum detrimenti meis rationibus allatum sit, satis intelligunt, qui saepius audierunt libellorum in regia magistrum me designatum, a principe antea fuisse." Epistola, République (1583), sig. e1r-v. For some discussion of this epistola and partial translation, see McRae ed., Six Books, p. A71-72. But Mark Greengrass has pointed out that avocats like Bodin were not usually appointed maître des requêtes. So this claim about a lost opportunity may constitute a form of wishful thinking and self-promotion, which resembles Bodin's later claim that he had been disappointed of the post of maître des requêtes in Alençon's household.

${ }^{32}$ I rely on the precise descriptions of Crahay et al., eds., Bibliographie critique, 10540. 
${ }^{33}$ Remonstrance au Roy concernant les pernicieux discours contenus au livre "de la republique" de Bodin (Paris, Fédéric Morel, 1579). The complete absence of further information and Bodin's own way of referring to him --"un certain personnage, qui se fait nommer de la Serre," Apologie in République (1583), f. 4r-- suggest that the name may be a pseudonym.

${ }^{34}$ In the Apologie see ff. 4r-5v on de La Serre, ff. 5v-10r on André Frankberger and other Germans, ff. 10r-12r on Pierre de l'Ostal and ff 12r-442 on Auger Ferrier. Bodin was responding to Andreas Franckenberger, De amplitudine et excellenti historiae propheticae dignitate (Wittenberg: Gronenberg, n.d. [ca. 1580]); Pierre de l'Ostal (or Hostal), Discours philosophiques, en nombre dix neuf, esquels est amplement traité de l'essence de l'âme et de la vertu morale (Paris, Jean Borel, 1579) and Auger Ferrier, Advertissements à M. J. Bodin sur le quatrième livre de sa République (Toulouse: Colomiès, 1580) or Advertissemens a M. Jean Bodin sur le quatriesme livre de sa Republique (Paris: Pierre Cavellat, 1580); see Mario Turchetti, "Jean Bodin," Stanford Encyclopedia of Philosophy, http://plato.stanford.edu/entries/bodin/

35 "Si Bodin eust voulu prendre sa cause en main, pour defendre son honneur, je n'eusse pas mis la main à la plume.... I'ay pensé que le tort m'estoit fait, estant du mesme pays et son amy: et me suis resolu de dresser une Apologie s'il ne voulait luy mesme se defendre. Et n'ayant la commodité de parler à luy, ie l'ay adverty par lettres, comme plusieurs autres, qu'il gardast la chose de ce monde la plus precieuse, c'est à sçavoir, l'honneur, mais il en a tenu si peu de compte qu' ... il m'a respondu par ses lettres du mois de Mars, ce que s'ensuit: 'Ego vero miror te Herpine, qui optime a doctrina, melius etiam a natura subornatus es, amicos urgere ad hos [for hoc] 
contentiosum, minimeque laudatum scribendi genus, quo quidem plerosque saepius abuti, sed qui moderate pro seipso uteretur vidi neminem. Ad patientiam, et eam, quae verum decus in se ipsa complectitur, modestiam cohortari potius debuisses. Sive enim amicorum, sive inimicorum iusta reprehensio est, cur non patienter feremus? .... Satis opinor, mea me scripta, et vitae anteactae rationes, ab improborum contumelia vindicabunt."' Apologie in République (1583), f. 2r-v. Bodin also stressed the importance of honour in his own voice; see for example the disquisition on honour in République (1583), V.iv (729 sqq.).

36 "Combien qu'il est mal aisé de s'en acquiter en son propre fait et ... parce qu'il est mal aisé, que celuy qui defend son honneur, (qui est plus cher que les biens de la vie) ne soit transporté de passions violentes, ou bien qu'il ne soit contraint de faire beaucoup de choses, qu'on ne peult dire sans rougir de honte, et principalement, quand il est question de l'honneur, qui se traite autrement que les anciens ne faisoient." Apologie in République (1583), f. 3r.

37 "Car quand la licence de mesdire, de laquelle usoient les Poëtes, et Ioueurs de farces, en nommant un chacun, ... pour les querelles qui en advenoient, fut defendue sur grandes peines, et rigoureuses, chacun se gardoit bien d'escrire contre l'honneur de personne: mais quand il fut question de defendre la Religion contre les Atheistes, ou la Republique contre les oppresseurs d'icelle, la pieté envers Dieu d'un costé, et l'amour de la patrie en l'autre a tousiours excusé les hommes ialoux de l'honneur de Dieu, et du bien public. Car comme disoit Theophraste, il est bien difficile que l'homme de bien s'abstienne de mesdire, parlant des mechans." Apologie in République (1583), f. 3r. 
${ }^{38}$ In the Methodus Bodin also warns against speaking ill (or well) of people by name; the good historian will only praise or blame someone who is dead: "nullius vero nisi mortui nomen laude prosequitur aut vituperatione.” Methodus (1572), 101. Following his own advice, he refused to name a historian whom he criticized on p. 67 , yet on other occasions Bodin also criticized and praised the living by name.

39 "Quand aux escrits des premiers autheurs, ils estoient comme saincts et inviolables. Car mesmes quand il advint à Zoile d'escrire un livre contre l'honneur d'Homere, ... pour cette cause principalement il fut precipité du haut de la roche Schirronide. Et iaçoit que plusieurs trouvoient ses reprehensions fondees en quelques raisons, si est-ce qu'il fut trouvé inexcusable d'attenter à un tel personnage, qui estoit à tous les peuples et Princes, comme un patron d'honneur." Apologie in République (1583), f. 3r. The Oxford Latin Dictionary (s.v. Scironius) reports that the Scironic rocks were "cliffs on the road from Athens to Megaris over which Sciron [a local brigand] was said to have kicked his victims."

${ }^{40}$ Frederick Tupper, "The envy theme in prologues and epilogues," Journal of English and Germanic philolology 16:4 (1917), 551-72, especially 566-71 (he notes the association of Zoilus and Momus). A search for Zoilus in the EEBO (Early English Books On-line) database turned up 689 hits in 388 works between 1522 and 1700. By contrast a similar search yielded only two occurrences in the more selective collection of French texts in the ARTFL (American and French Research on the Treasures of the French Language) database: in Bodin's Apologie and in Joachim du Bellay, L'Olive (1549), 7: "A peu que je ne leur fay la responce que fist Virgile à un quiddam Zoile, 
qui le reprenoit d' emprunter les vers d' Homere. J' ay (ce me semble) ailleurs assez deffendu l' immitation." Latin references include: Erasmus, Adagiorum chiliades quatuor (Basel: Froben, 1551), 490, adage II, v, 8 ("Zoili"); Caelius Rhodiginus, Lectiones antiquae (Basel: Froben and Episcopius, 1542), book 21, ch. 41; Theodor Zwinger, Theatrum humanae vitae (Basel: Oporinus, 1565), 944 (under the heading of "libertatis nimiae in reprehendendo poena," punishment of excessive liberty in criticizing); but none of these contains the detail present in Bodin. The Suda Lexicon was the likely source for the precipitation from the rock, whether Bodin consulted it directly (for example in the Latin edition of Basel, 1544) or learned the story from an intermediate source. See Suidas, nunc primum integer Latinitate donatus (Geneva: Petrus et Jacobus Chouet, 1619), s.v. "Zôilos," (p. 1131). My source was Laurentius Beyerlinck, Magnum theatrum humanae vitae (Lyon: Huguetan, 1631), E77f ("eloquentia") and P440b ("poena") which contain the details in Bodin and list the Suda as the source.

41 "Le premier qui viola les loix et religion d'honneur fut Aristote, lequel a esté blasmé de tous les Academitiens, d'avoir non seulement repris son maistre a tort, ains encores, de l'avoir souvent calomnié." Apologie in République (1583), f. 3v.

42 "Car combien que celuy qui traite quelque science peut blasmer l'impieté des meschans avec acerbité de paroles, et l'erreur de ceux qui ont failly, avec telle modestie qui appartient aux hommes de lettres. Si est ce, que c'est chose de mauvais et pernicieux exemple, de blasmer l'honneur des gens doctes, sous ombre de quelque faute, et les charger de paroles contumelieuses à la forme des Pedantes, pour loyer et salaire de leur travail: en quoy la Republique a notable interest: et beaucoup plus si on 
vient attenter à l'honneur par libelles diffamatoires: comme a fait depuis six ou sept mois contre la Republique de Bodin un certain personnage, qui se fait nommer de la Serre." Apologie in République (1583), f. 4r. Bodin also stressed the importance of protecting writers from unfair attack in the Methodus: "Interest enim Reipub. iudicia de scriptoribus qui in publicum exeunt, incorrupta minimeque depravata videri: ne cum alienae industriae modum ponere volumus, optimos quosque a scriptione deterreamus." Methodus (1572), 54.

43 "[P]eu auparavant deux calomniateurs, qui ne cessoient d'abayer [sic] publiquement contre ceste Republique, avoient esté par devant le Roy pour la faire defendre, le Roy leur fit dire par le seigneur d'Oron, Anagnoste Royal, qui avoit leu la Republique de Bodin, et que s'ils avoient quelque chose à dire contre luy, qu'ils le couchassent par escrit, pour en faire iugement. Au lieu de ce faire, apres un nommé la Serre, fist imprimer un petit livret, qu'il dedia au Roy. Le Roy l'ayant leu, et cognoissant les calomnies si grossieres, qu'on y void le iour au travers, il manda au Lieutenant civil, que la Serre fut mis en prison, et signa le decret de sa main, avec defenses à l'Imprimeur, sur la vie, d'exposer en vente son livret." Apologie in République (1583), f. 4 r.

44 "Quanquam Serranus ille qui in audito genere scribendi, ac probris inusitatis libellum complevit, ipsius principis iussu poenas graviores dedit, quam optare potuissem." Bodin's letter in Apologie in République (1583), f. $2 \mathrm{v}$.

45 "[C]e petit present lequel, s'il vous est aggreable, ie m'asseure si i'ay encores quelque malveillant, qu'il ne sera pas si mal advisé, que fut n'a pas long temps 
quelqu'un, que ie ne veux nommer pour son honneur, lequel dedia au Roy un libelle contre la Republique que i'ay mis en lumiere. Mais si tost que le Roy eut remarqué les propos calomnieux de cest homme-là: Il le fist constituer prisonnier, et signa le decret de sa main, avec deffenses sur la vie d'exposer son libelle en vente. Toutesfois il en est demeuré quitte pour une amende honorable: mais s'il eust esté de plus sain iugement, il eust merité la peine que Zoile receut pour un present pareil qu'il fist à Ptolemee Philadelphe Roy d'Aegypte. " Démonomanie (1580), dedication, sig. aijvaiijr.

46 "Or ie n'espere pas que personne escrive contre cest oeuvre, si ce n'est quelque Sorcier qui deffende sa cause: mais si i'en suis adverty, ie luy diray ce qu'on dict en plusieurs [lieux] de ce royaume [et] à ceux qui sont suspects d'estre Sorciers, d'autant loin qu'on les voit sans autre forme d'iniure ou crie à haute voix, IE ME DOUBTE, afin que les charmes et malefices de telles gens ne puissent offenser." Démonomanie (1580), dedication, sig. aiijr.

47 "Duo tamen sunt reprehensorum inter se dissidentium genera: alteri omnem de Republica quaestionem brevius terminari potuisse putant: alteri sine flagitio quicquam praetermitti debuisse negant. At cum singula quae sunt infinita contemplaremur, plurima nobis omittenda fuerunt, ut universa, id quo artium tradendarum proprium est, complecteremur. Iam enim pridem adolescens contritum illud a philosophis acceperam, nullam rerum singularum scientiam haberi." De republica (1586), Bodinus Iacobo Duvallo, sig. aijv. 
${ }^{48}$ Compare with: "En quoy, peut estre, il semblera que ie suis par trop long à ceux qui cherchent la briefveté: et les autres me trouveront trop court car l'oeuvre ne peut estre si grand, qu'il ne soit fort petit pour la dignité du subiet qui est presque infini." Preface, République (1583), sig. aiijr (first published 1576). "[Q]uae disputatio si nimis ampla cuiquam ac diffusa videbitur, cogitare debebit, ea quae nullum exitum habent, cuiusmodi est historia rerum humanarum, non posse brevi methodo contineri, quod si Galenus de sola methodo suae artis, quae certis regionibus concluditur, libros plusquam xxx Diomedes vero de re grammatica sex millia librorum effudit, profecto non debet id quod de universa historia scripsimus, copiosum videri." Methodus (1566), dedication, sig. **aiijr.

${ }^{49}$ A later example of a similar tactic, but with no shift in language, occurs in Jan Machielsen study of the two works published by the Jesuit Martin Delrio attacking Joseph Scaliger (in response to earlier polemics): the learned and moderate Vindiciae areopagiticae (Antwerp: Moretus, 1607) and the more trenchant Peniculus foriarum (Marburg: apud Haeredes Matthianos, 1609) published under the pseudonym Liberius Sanga Verinus and a false imprint. The latter lists all the insults that Scaliger used against Delrio in order to refute them and adds a list of pejoratives used against Scaliger, one for each letter of the alphabet from "Aerugo mera" (bitter envy) to "Zoilus." See Jan Machielsen, "Demons \& Letters; Aspects of the Life and Works of Martin Delrio (1551-1608)" (DPhil thesis, Oxford University, 2010) 296-98, 304-7. I am grateful to Jan Machielsen for this valuable comparative reference.

50 "Quae [threat of shipwreck of the state] me causa impulit hoc quicquid est quod de Republica conceperam, meis popularibus posteaquam a bellis paululum 
conquievissent, edere ac proponere ad intuendum. ... [persuaded to compose version in Latin] Igitur interpretandi religione soluti, nonnulla detraximus, plurima emendavimus, plura etiam adiecimus, et ea quae de iure maiestatis, deque magistratuum officiis, imperio, potestate: quae item de iure foeciali minus accurate, vel obscure scripta videbantur, facilioribus illustravimus et rationibus et exemplis, caput etiam integrum, quod res ita postularet, de ordinibus civium disputationi de corporibus et collegiis subiunximus." De republica (1586), dedication, sig. aijr-v. Similarly, in the dedicatory epistle to the Methodus, Bodin shifted to the first person plural at various points when he described his work; see Methodus (1572), 4, 7, 8, 10 .

${ }^{51}$ See the passage in the Epistola cited above note 30.

52 "Depuis la premiere edition de ce livre, le Docteur Cujas ne pouvant nier que cest erreur ne fust notable, d'appeller les iours d'assignation, et jours prefix dies fatales, s'est efforcé de faire entendre à ses disciples que Bodin n'a pas corrigé la faute du mot, kurias hêmeras au lieu de kêrias hêmeras, qui toutefois se lit en toutes les editions des authentiques imprimees depuis cinquante ans...." République (1583), III.vi, 468-69. See also Bodin's argument with Cujas over "deductis aetatibus"--an ancient law concerned about the age of houses, not their size as Cujas maintained. "Depuis la seconde edition, Bodin a esté adverti que Cuias s'est opiniastré en son interpretation, par laquelle il veut qu'on estime les edifices à l'aune." République (1583), IV.ii, 545.

${ }^{53}$ On the role of amanuenses and other helpers in the work of early modern scholars see Ann Blair, Too Much To Know: Managing Scholarly Information Before the Modern Age (New Haven: Yale University Press, 2010), 102-112. 